\title{
PENGARUH SUBSTITUSI TEPUNG UBI JALAR KUNING (Ipomoea batatas L) DAN TEPUNG WORTEL (Daucus carota L) TERHADAP KARAKTERISTIK ORGANOLEPTIK DAN NILAI GIZI BISKUIT
}

\author{
[Effect of Yellow Sweet Potato (Ipomoea batatas L) Flour and Carrot (Daucus carota L) Flour Substitution on \\ Organoleptic Characteristics and Nutritional Value of Biscuits]
}

\author{
Fatmasari ${ }^{*}$, Ansharullah ${ }^{1}$, Mariani $^{1}$ \\ 1Jurusan IImu dan Teknologi Pangan, Fakultas Pertanian, Universitas Halu Oleo, Kendari \\ *Email: fatmasariitp015@gmail.com (Telp: +6285397847367)
}

Diterima tanggal 20 September 2019,

Disetujui tanggal 06 November 2019

\begin{abstract}
This study aimed to determine the effect of yellow sweet potato flour and carrot flour substitution on the organoleptic characteristics and nutritional value of biscuits. This study used a completely randomized design (CRD) with five treatments K0 (0\% yellow sweet potato flour: $0 \%$ carrot flour: $100 \%$ wheat flour), $K 1$ (75\% yellow sweet potato flour: $5 \%$ carrot flour: $20 \%$ wheat flour ), K2 (70\% yellow sweet potato flour: 10\% carrot flour: $20 \%$ wheat flour), K3 (65\% yellow sweet potato flour: $15 \%$ carrot flour: $20 \%$ wheat flour), and K4 (60\% yellow sweet potato flour: $20 \%$ carrot flour: $20 \%$ wheat flour). Data were analyzed using analysis of variances (ANOVA). The results show that the substitution treatment of yellow sweet potato flour and carrot flour had a very significant effect on the organoleptic improvement of color, aroma, and taste. The most preferred treatment was the K1 treatment with preference values of color, aroma, texture, and taste reached 4.12 (very like), 4.40 (very like), 3.95 (like), and 4.07 (very like), respectively. The selected treatment had $4.66 \%$ water, $2.16 \%$ ash, $15.91 \%$ fat, $5.44 \%$ protein, $71.83 \%$ carbohydrate, and $2.15 \mathrm{mg} / \mathrm{g} \beta$ - carotene. Based on the SNI 01-2973-1992 standard, the yellow sweet potato flour and carrot flour biscuit products met the quality standards on water, fat, and carbohydrate contents.
\end{abstract}

Keywords: yellow sweet potato flour, carrot flour, wheat flour, biscuits.

\section{ABSTRAK}

Penelitian ini bertujuan untuk menentukan pengaruh substitusi tepung ubi jalar kuning dan tepung wortel terhadap karakteristik organoleptik dan nilai gizi biskuit. Penelitian ini menggunakan rancangan acak lengkap (RAL) dengan lima perlakuan KO (Tepung ubi jalar kuning $0 \%$ : tepung wortel $0 \%$ : Tepung terigu 100\%), K1 (Tepung ubi jalar kuning 75\% : tepung wortel $5 \%$ : tepung terigu 20\%), K2 (Tepung ubi jalar kuning $70 \%$ : tepung wortel $10 \%$ : tepung terigu $20 \%$ ), K3 (Tepung ubi jalar kuning $65 \%$ : tepung wortel $15 \%$ : tepung terigu 20\%), K4 (Tepung ubi jalar kuning $60 \%$ : tepung wortel $20 \%$ : tepung terigu 20\%).. Data dianalisis menggunakan analysis of variances (ANOVA). Hasil penelitian menunjukkan bahwa perlakuan substitusi tepung ubi jalar kuning dan tepung wortel berpengaruh sangat nyata terhadap peningkatan organoleptik warna, aroma dan rasa. Perlakuan terpilih diperoleh dari perlakuan K1 dengan nilai kesukaan terhadap warna sebesar 4,12 (sangat suka), aroma sebesar 4,40 (sangat suka), tekstur sebesar 3,95 (suka) dan rasa sebesar 4,07 (sangat suka). Perlakuan terpilih memiliki nilai kimia biskuit yaitu kadar air sebesar 4,66\%, kadar abu sebesar 2,16\%, kadar lemak sebesar $15,91 \%$, kadar protein sebesar 5,44\%, kadar karbohidrat sebesar 71,83\% dan kadar $\beta$-karoten sebesar 2,15 mg/g. Berdasarkan standar mutu SNI 01-2973-1992 bahwa produk biskuit tepung ubi jalar kuning dan tepung wortel telah memenuhi standar mutu SNI pada kadar air, kadar lemak dan kadar karbohidrat.

Kata kunci: tepung ubi jalar kuning, tepung wortel, tepung terigu, biskuit. 


\section{PENDAHULUAN}

Ubi jalar kuning (Ipomoea batatas L) merupakan salah satu komoditas tanaman pangan yang dapat tumbuh dan berkembang di seluruh Indonesia (Claudia et al., 2015). Ubi jalar juga merupakan sumber karbohidrat dan sumber energi serta mengandung vitamin dan mineral seperti Zat Besi (Fe), Fosfor (P), Kalsium (Ca), dan Natrium (Na). Salah satu vitamin yang terdapat pada ubi jalar antara lain vitamin A (terdapat dalam bentuk betakaroten) terutama pada jenis ubi jalar kuning (Erawati, 2006). pengolahan ubi jalar kuning menjadi tepung merupakan salah satu cara pengawetan dan penghematan ruang penyimpanan (Claudia et al., 2015). Tepung ubi jalar kuning yang merupakan bahan setengah jadi untuk industri pangan dapat dimanfaatkan dalam pembuatan produk pangan salah satunya adalah biskuit.

Biskuit adalah makanan selingan (snack) yang sangat digemari oleh semua kalangan masyarakat dalam segala umur. Biskuit merupakan produk yang diperoleh dengan memanggang adonan yang berasal dari tepung terigu dengan penambahan makanan lain dan dengan atau penambahan bahan tambahan pangan yang diizinkan. Biskuit diklasifikasikan dalam empat jenis yaitu biskuit keras, crackers, cookies dan wafer (Badan Standardisasi Nasional, 2011). Biasanya formulasi biskuit dibuat dengan diperkaya bahan-bahan tambahan seperti lemak, gula (ataupun garam) serta bahan pengembang. Biskuit dibuat dengan bermacam-macam jenis, terutama dibedakan atas keseimbangan yang ada antara bahan utama tepung, gula, lemak, dan telur. Kemudian juga bahan tambahan seperti coklat, buah-buahan, dan rempah-rempah yang memiliki pengaruh terhadap cita rasa (Omobuwoajo, 2003). Salah satu penambahan pada biskuit ini wortel.

Tanaman wortel (Daucus carota L) merupakan tumbuhan jenis sayuran yang banyak tumbuh di Indonesia dan produksinya cukup tinggi. Wortel adalah sayuran yang kaya akan provitamin $A$, atau disebut juga betakaroten, yang dapat berfungsi sebagai antioksidan, membantu melindungi tubuh terhadap penyakit cardiovaskular dan kanker, meningkatkan penglihatan, terutama penglihatan malam hari. Wortel juga mengandung pektin yang baik untuk menurunkan kolestrol darah, serat yang tinggi dalam wortel juga mencegah terjadihnya konstipasi (Astuti, 2004). Bagian yang dapat dimakan dari wortel adalah bagian umbi atau akarnya, kandungan vitamin A pada wortel cukup tinggi yaitu 12000 SI. Kadar air wortel cukup tinggi yaitu sebesar $88 \%$ yang menyebabkan wortel segar mudah rusak sehingga penanganan pascapanennya harus optimal (Nuansa, 2011 dalam Ma'hadah, 2015).

Pengolahan wortel menjadi tepung bertujuan untuk memperpanjang daya simpan wortel, mempermudah transportasi dan pengolahan selanjutnya. Akan tetapi dalam pengolahan tepung wortel harus memperhatikan prosedur pengolahan yang baik karena jika proses pengolahan dilakukan tanpa memperhatikan prosedur pengolahan yang baik maka akan menurunkan kandungan gizi terutama senyawa bioaktif yang terdapat dalam 
wortel tersebut. Oleh karena itu, dengan memperhatikan cara pengolahan yang baik diharapkan cara pengolahan ini dapat menghasilkan tepung wortel yang berkualitas (Rahmayani et al., 2017).

Berdasarkan hasil penelitian yang dilakukan oleh Sumarni, (2017) yaitu pembuatan cookies dengan penambahan tepung ubi jalar kuning dan tepung ikan kakap dalam rasio (tepung ubi jalar kuning $75 \%$ : tepung ikan kakap 5\%: tepung terigu 20\%) memiliki kandungan gizi kadar air sebesar 8,43\%, abu sebesar 2,57\%, lemak sebesar $9,07 \%$, protein sebesar $13,57 \%$ dan karbohidrat sebesar $66,36 \%$. Penelitian yang dilakukan oleh Febrina (2012), yang menambahkan tepung wortel dalam pembuatan biskuit terbukti dapat menambah kadar vitamin $\mathrm{A}$.

Berdasarkan uraian diatas, maka dilaporkan hasil penelitian tentang pengaruh substitusi tepung ubi jalar kuning (Ipomoea batatas L) dan tepung wortel (Daucus carota L) terhadap karakteristik organoleptik dan nilai gizi biskuit. Substitusi tepung ubi jalar kuning dan tepung wortel diharapkan akan meningkatkan penilaian organoleptik dan kandungan gizi pada biskuit, sehingga dapat menjadi salah satu produk pangan alternatif yang praktis yang dapat diterima di masyarakat.

\section{BAHAN DAN METODE}

\section{Bahan}

Bahan yang digunakan pada penelitian ini antara lain bahan utama adalah ubi jalar kuning (Ipomoea batatas $\mathrm{L}$ ) dan wortel (Daucus carota $\mathrm{L}$ ) dari Kota Kendari dan terigu. Bahan tambahan adalah margarin, telur, garam, gula halus, susu skim dan baking powder. Bahan kimia yang digunakan dalam analisis adalah $\mathrm{K}_{2} \mathrm{SO}_{4}$ (teknis), $\mathrm{HgO}$ (teknis), $\mathrm{H}_{2} \mathrm{SO}_{4}$ 0,1 (teknis), $\mathrm{NaOH}-\mathrm{Na}_{2} \mathrm{SO}_{3}$ (teknis), $\mathrm{H}_{3} \mathrm{BO}_{3}$ (teknis), $\mathrm{HCl} 0,02 \mathrm{~N}$ (teknis), $\mathrm{HNO}_{3}$ (teknis), $\mathrm{HClO}_{4}$ (teknis).

\section{Tahapan Penelitian}

\section{Pembuatan tepung ubi jalar kuning (Hardiyanti, 2018)}

Ubi jalar kuning disortasi dan pembersihan, kemudian dikupas dengan menggunakan pisau stainless steel lalu dicuci, proses pencucian menggunakan air bersih yang mengalir untuk menghilangkan kotoran pada permukaan umbi dan ditiriskan, kemudian dikukus selama 7 menit dan didinginkan selama 5 menit, selanjutnya ubi jalar kuning diris dengan ketebalan $0,3 \mathrm{~cm}$. Pengeringan dilakukan menggunakan oven pada suhu $60^{\circ} \mathrm{C}$ selama $12 \mathrm{jam}$, kemudian dihaluskan dengan menggunakan blender lalu diayak dengan ayakan 80 mesh.

\section{Pembuatan tepung wortel (Hardianti et al., 2018)}

Umbi wortel disortasi, dipilih wortel yang utuh umbinya (tidak cacat). Umbi wortel yang telah dipilih kemudian dicuci menggunakan air bersih, dikupas menggunakan pisau stainless steel, kemudian dipotong 
menjadi bagian kecil-kecil setelah itu dimasukkan dalam oven pada suhu $60^{\circ} \mathrm{C}$ selama 8 jam. Setelah kering kemudian dihaluskan dengan menggunakan blender dan diayak dengan menggunakan ayakan 80 mesh.

\section{Pembuatan Biskuit (Margaret, 2010)}

Metode pembuatan biskuit dilakukan dengan cara terlebih dahulu menyiapkan bahan yang akan digunakan. Mengocok telur $60 \mathrm{~g}$, gula $20 \mathrm{~g}$, dan mentega $30 \mathrm{~g}$ sampai adonan mengembang selama 5 menit, kemudian masukan tepung ubi jalar kuning, tepung wortel, tepung terigu yang telah diayak (sesuai komposisi perlakuan penelitian), vanili $1 \mathrm{~g}$, baking powder $2 \mathrm{~g}$, susu skim $10 \mathrm{~g}$, dan garam $1 \mathrm{~g}$ dikocok menggunakan alat mixer hingga kalis. Selanjutnya adonan dibentuk dan dicetak, kemudian dimasukkan ke dalam oven pada suhu $130^{\circ} \mathrm{C}$ selama 15 menit.

\section{Rancangan Penelitian}

Rancangan yang digunakan dalam penelitian ini adalah rancangan acak lengkap (RAL) yang terdiri dari 5 perlakuan yaitu: $\mathrm{K} 0$ (Tepung ubi jalar kuning $0 \%$ : tepung wortel $0 \%$ : Tepung terigu $100 \%$ ), $\mathrm{K} 1$ (Tepung ubi jalar kuning $75 \%$ : tepung wortel $5 \%$ : tepung terigu 20\%), K2 (Tepung ubi jalar kuning $70 \%$ : tepung wortel $10 \%$ : tepung terigu 20\%), K3 (Tepung ubi jalar kuning 65\% : tepung wortel 15\% : tepung terigu 20\%), K4 (Tepung ubi jalar kuning $60 \%$ : tepung wortel $20 \%$ : tepung terigu 20\%). Masing-masing perlakuan diulang sebanyak 4 kali sehingga diperoleh 20 unit percobaan. Rancangan ini berdasarkan hasil penelitian pendahuluan.

\section{Variabel Pengamatan}

Pengamatan pada penelitian ini yaitu uji organoleptik diantaranya warna, aroma, tekstur, dan rasa untuk mengetahui tingkat kesukaan panelis, dengan menggunakan 30 orang panelis tidak terlatih yang memberikan penilaiannya. Kemudian dilanjutkan dengan analisis proksimat biskuit dari perlakuan terbaik yang diperoleh dari uji organoleptik terdiri dari analisis kadar air metode thermogravimetri (AOAC, 2005), abu metode thermogravimetri (AOAC, 2005), protein metode biuret (AOAC, 2005), lemak metode Soxhlet (AOAC, 2005), karbohidrat yang dihitung berdasarkan metode by difference (Winarno, 2004) dan $\beta$-karoten metode spektrofotometri (Tejasari, 2005).

\section{Analisis Data}

Data dianalisis dengan menggunakan sidik ragam ANOVA (analysis of varian), dari hasil analisis ragam menunjukkan nilai $\mathrm{F}$ hitung> $\mathrm{F}$ tabel, dilanjutkan dengan uji Duncan's multiple range test (DMRT) pada taraf kepercayaan $95 \%(\mathrm{a}=0,05)$. 


\section{HASIL DAN PEMBAHASAN}

\section{Hasil Uji Organoleptik}

Rekapitulasi hasil analisis pengaruh substitusi tepung ubi jalar kuning dan tepung wortel terhadap pengujian organoleptik produk biskuit meliputi warna, aroma, tekstur dan rasa disajikan pada Tabel 1.

Tabel 1. Rekapitulasi analisis sidik ragam pengaruh substitusi tepung ubi jalar kuning dan tepung wortel terhadap pengujian organileptik biskuit.

\begin{tabular}{ccc}
\hline No & Variable pengamatan & Analisis sidik ragam \\
\hline 1 & Organoleptik Warna & $* *$ \\
2 & Organoleptik Aroma & $* *$ \\
3 & Organoleptik Tekstur & $*$ \\
4 & Organoleptik Rasa & $* *$ \\
\hline
\end{tabular}

Keterangan: ${ }^{* *}=$ berpengaruh sangat nyata, $\mathrm{tn}=$ berpengaruh tidak nyata

Berdasarkan data Tabel 1, menunjukkan bahwa perlakuan substitusi tepung ubi jalar kuning dan tepung wortel berpengaruh sangat nyata terhadap warna, aroma dan rasa serta berpengaruh nyata terhadap tekstur biskuit.

\section{Warna}

Berdasarkan hasil analisis sidik ragam diketahui bahwa perlakuan substitusi tepung ubi jalar kuning dan tepung wortel berpengaruh sangat nyata terhadap penilaian organoleptik warna biskuit. Hasil uji lanjutan $\left(\mathrm{DMRT}_{0,05}\right)$ pengaruh substitusi tepung ubi jalar kuning dan tepung wortel disajikan pada Tabel 2.

Tabel 2. Rerata penilaian organoleptik warna biskuit pengaruh substitusi tepung ubi jalar kuning dan tepung wortel

\begin{tabular}{cccc}
\hline Simbol & $\begin{array}{c}\text { Perlakuan } \\
\text { (TUJK : TW : TT)(\%) }\end{array}$ & $\begin{array}{c}\text { Rerata Organoleptik } \\
\text { Warna }\end{array}$ \\
\hline K0 & $(100: 0: 0)$ & $3,77^{\mathrm{b}} \pm 0,73$ & Kategori \\
K1 & $(75: 5: 20)$ & $4,12^{\mathrm{a}} \pm 0,75$ & Suka \\
K2 & $(70: 10: 20)$ & $3,67^{\mathrm{b}} \pm 0,57$ & Sangat Suka \\
K3 & $(65: 15: 20)$ & $3,35^{\mathrm{c}} \pm 0,86$ & Suka \\
K4 & $(60: 20: 20)$ & $3,15^{\mathrm{c}} \pm 0,86$ & Suka \\
\hline
\end{tabular}

Keterangan: Angka-angka yang diikuti oleh huruf yang berbeda menunjukan beda nyata menurut uji lanjut Duncan pada taraf a 0,05. Tepung Ubi Jalar Kuning (TUJK), Tepung Wortel (TW) dan Tepung Terigu (TT).

Berdasarkan Tabel 2, menunjukkan hasil penilaian warna biskuit dengan nilai tertinggi 4,12 (sangat suka) terdapat pada perlakuan K1 sedangkan nilai terendah 3,15 (suka) terdapat pada perlakuan K4. Biskuit pada perlakuan $\mathrm{K} 1$ disukai panelis karena memiliki warna yang coklat terang. Hal ini diduga karena konsentrasi penambahan tepung ubi jalar kuning $75 \%$ dan tepung wortel $5 \%$, akan membuat produk biskuit yang dihasilkan 
berwana terang. Sedangkan perlakuan K4 dengan konsentrasi penambahan tepung ubi jalar kuning $60 \%$ dan tepung wortel 20\% akan menghasilkan produk biskuit yang berwarna orange kecoklatan, sehingga biskuit kurang disukai oleh panelis. Hal ini sesuai dengan hasil penelitian Putri (2015), yang menyatakan bahwa penggunaan jenis tepung yang berbeda akan mempengaruhi warna yang dihasilkan. Dimana tepung ubi jalar kuning yang ditambahkan pada biskuit sebesar 80\% mempunyai warna yang agak gelap. Hal ini sesuai hasil penelitian Hastuti (2011), yang menyatakan bahwa penambahan tepung wortel $20 \%$ pada kue kering memberikan pengaruh nyata terhadap penerimaan warna kue kering yang dihasilkan.

\section{Aroma}

Berdasarkan hasil analisis sidik ragam diketahui bahwa perlakuan subtitusi tepung ubi jalar kuning dan tepung wortel berpengaruh sangat nyata terhadap penilaian organoleptik aroma biskuit. Pengaruh substitusi tepung ubi jalar kuning dan tepung wortel terhadap penilaian organoleptik aroma biskuit disajikan pada Tabel 3.

Tabel 3. Rerata penilaian organoleptik aroma biskuit pengaruh substitusi tepung ubi jalar kuning dan tepung wortel.

\begin{tabular}{cccc}
\hline Simbol & Perlakuan & Rerata Organoleptik & Kategori \\
\hline K0 & $(100: 0: 0)$ & Aroma & Suka \\
K1 & $(75: 5: 20)$ & $3,67^{\mathrm{b}} \pm 0,69$ & Sangat Suka \\
K2 & $(70: 10: 20)$ & $4,40^{\mathrm{a}} \pm 0,87$ & Sangat Suka \\
K3 & $(65: 15: 20)$ & $4,22^{\mathrm{a}} \pm 0,69$ & Suka \\
K4 & $(60: 20: 20)$ & $3,85^{\mathrm{b}} \pm 0,89$ & Suka \\
\hline
\end{tabular}

Keterangan: Angka-angka yang dilkuti oleh huruf yang berbeda menunjukan beda nyata menurut uji lanjut Duncan pada taraf a 0,05. Tepung Ubi Jalar Kuning (TUJK), Tepung Wortel (TW) dan Tepung Terigu (TT).

Berdasarkan data Tabel 3, menunjukkan hasil penilaian aroma biskuit dengan nilai tertinggi 4,40 (sangat suka) terdapat pada perlakuan K1 sedangkan nilai terendah 3,57 (suka) terdapat pada perlakuan K4. Berdasarkan hasil penilaian organoleptik aroma, semakin banyak tepung wortel yang ditambahkan pada pembuatan biskuit maka aroma yang dihasilkan cenderung semakin tidak disukai oleh panelis, hal ini diduga karena aroma dari tepung wortel yang langu. Hal ini sesuai dengan hasil penelitian Aminah et al., (2018) yang menyatakan bahwa semakin banyak penambahan tepung wortel $30 \%$ pada cookies maka aroma kurang disukai oleh panelis, hal ini disebabkan karena aroma cookies dipengaruhi oleh aroma tepung wortel yang langu. Hal ini sesuai dengan hasil penelitian Sumarni et al., (2017) bahwa semakin banyak konsentrasi penambahan tepung ubi jalar kuning $75 \%$ pada produk cookies semakin disukai oleh panelis dikarenakan oleh bau khas ubi jalar kuning itu sendiri.

\section{Tekstur}


Berdasarkan hasil analisis sidik ragam diketahui bahwa perlakuan subtitusi tepung ubi jalar kuning dan tepung wortel berpengaruh nyata terhadap penilaian organoleptik tekstur biskuit. Pengaruh subtitusi tepung ubi jalar kuning dan tepung wortel terhadap penilaian organoleptik rasa biskuit disajikan pada Tabel 4 .

Tabel 4. Rerata penilaian organoleptik tekstur biskuit pengaruh subtitusi tepung ubi jalar kuning dan tepung wortel

\begin{tabular}{cccc}
\hline & Perlakuan & Rerata Organoleptik & Kategori \\
\hline Simbol & Tekstur & \\
\hline K0 & $(100: 0: 0)$ & $3,0)$ & Suka \\
K1 & $(75: 5: 20)$ & $3,35^{\mathrm{b}} \pm 0,73$ & Suka \\
K2 & $(70: 10: 20)$ & $3,95^{\mathrm{a}} \pm 0,67$ & Suka \\
K3 & $(65: 15: 20)$ & $3,47^{\mathrm{b}} \pm 0,61$ & Suka \\
K4 & $(60: 20: 20)$ & $3,25^{\mathrm{b}} \pm 0,87$ & Suka \\
\hline
\end{tabular}

Keterangan: Angka-angka yang diikuti oleh huruf yang berbeda menunjukan beda nyata menurut uji lanjut Duncan pada taraf a 0,05. Tepung Ubi Jalar Kuing (TUJK), Tepung Wortel (TW) dan Tepung Terigu (TT).

Berdasarkan data Tabel 4, menunjukkan hasil penilaian tekstur biskuit dengan nilai tertinggi 3,95 (suka) terdapat pada perlakuan $\mathrm{K} 1$ sedangkan nilai terendah 3,27 (suka) terdapat pada perlakuan $\mathrm{K} 4$, hal ini diduga karena semakin tinggi penambahan tepung wortel pada pembuatan biskuit maka tekstur yang dihasilkan makin tidak disukai oleh panelis. Hal ini sesuai dengan hasil penelitian Hastuti (2011), yang menyatakan bahwa penambahan tepung wortel 20-40\% mempunyai tekstur yang agak keras. Tepung wortel dapat mensubstitusi tepung terigu dalam pembuatan biskuit hanya sampai batas tertentu atau dalam jumlah kecil. Hal ini sesuai dengan hasil penelitian Nindrayani et al., (2011) yang menyatakan bahwa semakin tinggi penambahan 80\% tepung ubi jalar kuning pada pembuatan biskuit maka tekstur pada produk biskuit akan semakin keras. Hal ini dikarenakan tepung ubi jalar kuning mengandung amilosa yang lebih tinggi dibandingkan dengan tepung terigu. Amilosa yang tinggi dapat mengakibatkan struktur granula pati lebih kokoh dan keras membentuk kristal sehingga tekstur biskuit menjadi keras.

\section{Rasa}

Berdasarkan hasil analisis sidik ragam diketahui bahwa perlakuan substitusi tepung ubi jalar kuning dan tepung wortel berpengaruh sangat nyata terhadap penilaian organoleptik rasa biskuit. Pengaruh substiusi tepung ubi jalar kuning dan tepung wortel terhadap penilaian organoleptik rasa biskuit disajikan pada Tabel 5 .

Tabel 5. Rerata penilaian organoleptik rasa biskuit pengaruh substitusi tepung ubi jalar kuning dan tepung wortel.

\begin{tabular}{cccc}
\hline Simbol & $\begin{array}{c}\text { Perlakuan } \\
\text { (TUJK: TW }: \text { TT) }(\%)\end{array}$ & $\begin{array}{c}\text { Rerata Organoleptik } \\
\text { Rasa }\end{array}$ & Kategori \\
\hline K0 & $(0: 0: 100)$ & $3,72^{\mathrm{b}} \pm 0,59$ & Suka \\
K1 & $(75: 5: 20)$ & $4,07^{\mathrm{a}} \pm 0,79$ & Sangat Suka \\
K2 & $(70: 10: 20)$ & $3,82^{\mathrm{b}} \pm 0,81$ & Suka \\
K3 & $(65: 15: 20)$ & $3,5^{\circ} \pm 0,90$ & Suka \\
K4 & $(60: 20: 20)$ & $3,45^{\circ} \pm 0,50$ & Suka \\
\hline
\end{tabular}


Keterangan: Angka-angka yang diikuti oleh huruf yang berbeda menunjukan beda nyata menurut uji lanjut Duncan pada taraf a 0,05. Tepung Ubi Jalar Kuning (TUJK), Tepung Wortel (TW) dan Tepung Terigu (TT).

Berdasarkan data Tabel 5, menunjukkan hasil penilaian rasa biskuit dengan nilai tertinggi 4,07 (sangat suka) terdapat pada perlakuan K1 sedangkan nilai terendah 3,45 (suka) terdapat pada perlakuan K4, hal ini diduga karena banyaknya penambahan tepung wortel pada biskuit sehingga bisa menurunkan rata-rata penerimaan panelis. Hal ini sesuai dengan hasil penelitian Firza (2014), yang menyatakan bahwa substitusi $30 \%$ tepung wortel dapat memberikan rasa khas wortel yang berbeda pada biskuit. Hal ini didukung oleh hasil penelitian Sumarni (2017), yang menyatakan bahwa semakin banyak penambahan tepung ubi jalar kuning pada pembuatan cookies maka rasa yang dihasilkan semakin disukai oleh panelis. Dimana tepung ubi jalar kuning yang ditambahkan pada pembuatan cookies sebesar $75 \%$.

\section{Analisis Nilai Gizi Biskuit}

Analisis nilai kandungan gizi biskuit terpilih meliputi, kadar air, abu, lemak, protein, karbohidrat dan kadar betakaroten disajikan pada Tabel 6 .

Tabel 6. Rekapitulasi perlakuan kontrol dan perlakuan terpilih analisis nilai gizi biskuit subtitusi tepung ubi jalar kuning dan tepung wortel.

\begin{tabular}{llccl}
\hline & & \multicolumn{2}{c}{ Perlakuan } & \multirow{2}{*}{ SNI (\%) } \\
\cline { 3 - 4 } No & Variabel Pengamatan (\%) & $\begin{array}{c}\text { K0 } \\
\text { (Biskuit Kontrol) }\end{array}$ & $\begin{array}{c}\text { K1 } \\
\text { (Biskuit Terpilih) }\end{array}$ & \\
\hline 1 & Kadar Air & $6,45 \pm 0,19$ & $4,66 \pm 0,14$ & Maksimal 5 \\
2 & Kadar Abu & $1,59 \pm 0,30$ & $2,16 \pm 0,18$ & Maksimal 1,5 \\
3 & Kadar Lemak & $16,31 \pm 0,41$ & $15,91 \pm 0,29$ & Minimal 9,5 \\
4. & Kadar protein & $3,46 \pm 0,09$ & $5,44 \pm 0,16$ & Minimal 9 \\
5. & Kadar karbohidrat & $72,81 \pm 0,21$ & $71,83 \pm 0,16$ & Minimal 70 \\
6. & Kadar betakaroten mg/g & 0,80 & 2,15 & - \\
\hline
\end{tabular}

\section{Kadar Air}

Berdasarkan data pada Tabel 6, menunjukkan bahwa kadar air dari perlakuan terpilih $\mathrm{K} 1$ dan perlakuan kontrol (tepung terigu 100\%) ada pengaruh berbeda nyata. Hasil pengujian menunjukkan bahwa kadar air pada biskuit diperoleh perlakuan tertinggi pada kontrol dengan kadar air sebesar 6,45\% yang melebihi standar SNI. Sedangkan yang terendah terdapat pada perlakuan K1 dengan kadar air sebesar 4,66\% yang memenuhi standar SNI. Kadar air biskuit yang ditentukan oleh SNI 01-2973-1992 yaitu maksimal 5\%. Tingginya kadar air pada kontrol disebabkan karena penggunaan 100\% tepung terigu, dimana tepung terigu memiliki kandungan air yang cukup tinggi yaitu 10,60\% (SNI, 2009). Selain itu tepung terigu memiliki kandungan protein gluten yang memiliki daya serap air yang lebih tinggi. Hal ini didukung oleh pernyataan dari Ferawati dan Siskayanti (2014), yang menyatakan bahwa protein gluten memiliki daya serap air lebih tinggi dibandingkan pati karena gluten 
memerlukan air lebih banyak agar gluten yang dibentuk dapat menyimpan gas sebanyak-banyaknya. Hal ini juga didukung oleh Subandoro et al., (2013) yang menyatakan bahwa dalam pembuatan cookies subtitusi tepung ubi jalar kuning mengandung kadar air sebesar $7 \%$.

\section{Kadar Abu}

Berdasarkan data pada Tabel 6, menunjukkan bahwa kadar abu dari perlakuan terpilih $\mathrm{K} 1$ dan perlakuan kontrol (tepung terigu 100\%) ada pengaruh berbeda tidak nyata. Hasil pengujian menunjukkan bahwa kadar abu pada biskuit diperoleh perlakuan tertinggi pada perlakuan K1 dengan kadar abu sebesar 2,16\% yang melebihi standar SNI, sedangkan kadar abu terendah terdapat pada kontrol dengan kadar abu sebesar 1,59\% yang memenuhi standar SNI. Kadar abu biskuit yang ditentukan oleh SNI 01-2973-1992 yaitu maksimal 1,5\%. Tingginya kadar abu pada perlakuan K1 diduga karena kandungan kadar abu yang ada pada bahan bakunya, hal ini sesuai dengan hasil penelitian Subandoro et al., (2013) yang menyatakan bahwa dalam pembuatan cookies subtitusi tepung ubi jalar kuning memiliki kadar abu sebesar 2,82\%. Hal ini sesuai dengan hasil penelitian Aminah et al. (2018) yang menambahkan tepung wortel dalam pembuatan cookies memiliki kadar abu sebesar $2,56 \%$. Artinya semakin banyak penambahan tepung ubi jalar kuning dan tepung wortel maka semakin tinggi kadar abu pada produk biskuit yang dihasilkan jika dibandingkan dengan perlakuan $\mathrm{K} 0$ yang menggunakan tepung terigu mengandung kadar abu sebesar 0,64g (SNI, 2009).

\section{Kadar Lemak}

Berdasarkan data pada Tabel 6, menunjukkan bahwa kadar lemak perlakuan terpilih $\mathrm{K} 1$ dan perlakuan kontrol (tepung terigu 100\%) ada pengaruh berbeda tidak nyata. Hasil pengujian menunjukkan bahwa kadar lemak pada biskuit diperoleh perlakuan tertinggi pada perlakuan kontrol dengan kadar lemak sebesar 16,31\% sedangkan yang terendah terdapat pada perlakuan K1 dengan kadar lemak sebesar 15,91\%. Hal ini menunjukan bahwa kadar lemak pada biskuit baik perlakuan K1 maupun kontrol sudah memenuhi syarat mutu SNI biskuit minimal 9,5\%. Namun menurunnya kadar lemak pada biskuit perlakuan K1 disebabkan oleh kandungan lemak dari bahan baku tepung yang digunakan. Hal ini sesuai dengan hasil penelitian Claudia dan Widjanarko (2016), yang menambahkan tepung ubi jalar kuning pada biskuit memiliki kadar lemak sebesar $0,23 \%$. Hal ini didukung oleh hasil penelitian Kurniawati (2010), yang menambahkan tepung wortel dalam pembuatan cookies memiliki kadar lemak sebesar 0,24\% lebih rendah jika dibandingkan dengan tepung terigu. Dimana, tepung terigu memiliki kandungan kadar lemak sebesar 1-3\% (Riganakos dan Kontominas, 1995). Hasil penelitian Winarno (2004), melaporkan bahwa lemak dan minyak terdapat pada hampir semua bahan pangan dengan kandungan yang berbeda-beda.

\section{Kadar Protein}


Berdasarkan data pada Tabel 6, menunjukkan bahwa kadar protein perlakuan terpilih K1 dan perlakuan kontrol (tepung terigu 100\%) ada pengaruh berbeda nyata. Hasil pengujian menunjukkan bahwa kadar protein tertinggi terdapat pada perlakuan K1 dengan nilai sebesar 5,44\% sedangkan kadar protein terendah terdapat pada kontrol dengan nilai sebesar 3,46\%. Hal ini menunjukkan bahwa kadar protein pada biskuit baik perlakuan K1 maupun kontrol belum memenuhi syarat mutu SNI biskuit yaitu minimal 9,5\%. Hal ini sesuai dengan hasil penelitian Wulandari dan Handarsari, (2010) melaporkan bahwa dari hasil analisis kandungan protein pada seluruh formulasi terjadi penurunan kandungan protein hal ini didasari pada teknik pengolahan setelah menjadi produk biskuit. Hal ini sesuai dengan hasil penelitian Kurniawati (2010), yang menyatakan bahwa penambahan tepung wortel pada pembuatan cookies kadar proteinnya tidak mengalami peningkatan yang besar karena tepung wortel mempunyai kandungan protein rendah yaitu $3,23 \%$ dan tepung ubi jalar kuning mengandung kadar protein sebesar 4,34\% (Claudia dan Widjanarko, 2016).

\section{Kadar Karbohidrat}

Berdasarkan data pada Tabel 6, menunjukkan bahwa kadar karbohidrat perlakuan terpilih K1 dan perlakuan kontrol (tepung terigu 100\%) ada pengaruh berbeda tidak nyata. Hasil pengujian menunjukkan bahwa kadar karbohidrat tertinggi terdapat pada perlakuan K1 dengan nilai sebesar $72,81 \%$ sedangkan kadar karbohidrat terendah terdapat pada kontrol dengan nilai sebesar $71,81 \%$. Kadar karbohidrat pada penelitian ini memenuhi standar yang telah ditentukan oleh SNI 01-2973-1992 yaitu minimum 70\%. Kadar karbohidat perlakuan terpilih pada penelitian ini yaitu K1 (subtitusi tepung ubi jalar kuning $75 \%$ ) lebih tinggi daripada kandungan karbohidrat pada hasil penelitian Sumarni et al., (2017) yang melaporkan bahwa penambahan tepung ubi jalar kuning pada produk cookies memiliki kadar karbohidrat sebesar $66,36 \%$. Hal ini sejalan dengan hasil penelitian Sugito dan Hayati (2006), bahwa kadar karbohidrat yang dihitung secara By difference dipengaruhi oleh komponen nutrisi lain, semakin rendah komponen nutrisi lain maka kadar karbohidrat akan semakin tinggi. Begitu juga sebaliknya semakin tinggi komponen nutrisi lain maka kadar karbohidrat akan semakin rendah. Akan tetapi, walaupun jumlah maksimal dan minimal dari komponen gizi dihitung menurut SNI 01-2973-1992. Namun, komponen nutrisi yang bisa mempengaruhi besarnya kandungan karbohidrat diantaranya adalah kandungan kadar air, kadar abu, kadar lemak dan kadar protein.

\section{Kadar Betakaroten}

Berdasarkan data pada Tabel 6, menunjukan bahwa kadar betakaroten perlakuan terpilih $\mathrm{K} 1$ dan perlakuan kontrol (tepung terigu 100\%) ada pengaruh berbeda nyata. Hasil pengujian menunjukkan bahwa terdapat kandungan $\beta$-Karoten pada biskuit perlakuan $\mathrm{K} 1$ sebesar 2,15 $\mathrm{mg} / \mathrm{g}$ sedangkan untuk kandungan $\beta$ karoten pada kontrol biskuit $\mathrm{K} 0$ sebesar $0,80 \mathrm{mg} / \mathrm{g}$. Hal ini sesuai dengan hasil penelitian Febrina (2012), yang 
menyatakan bahwa berdasarkan penambahan tepung wortel 5\%, 15\% dan 25\% terbukti menambah kadar vitamin A. Hasil penelitian ini menunjukkan bahwa biskuit dengan penambahan tepung wortel sebanyak $5 \%$ dan $15 \%$ disukai panelis baik dalam segi rasa, aroma maupun tekstur. Hal ini sesuai dengan hasil penelitian Hardianti et al., (2018), yang menyatakan bahwa semakin tinggi penggunaan tepung ubi jalar kuning dan tepung wortel maka semakin tinggi pula kadar $\beta$-Karoten pada biskuit karena dipengaruhi oleh banyaknya tepung ubi jalar kuning dan tepung wortel yang ditambahkan. Hasil penelitian Margaret (2010), yang menyatakan bahwa tepung ubi jalar kuning memiliki kandungan $\beta$-karoten sebesar $5,9949 \mathrm{mg} / 100 \mathrm{~g}$ dan kadar $\beta$-karoten dalam $100 \%$ tepung wortel sebanyak $44.9212 \mu g / g$ (Hariko, 2013).

\section{KESIMPULAN}

Terdapat pengaruh sangat nyata terhadap warna, aroma, rasa dan pengaruh nyata terhadap tekstur. Berdasarkan hasil penilaian organoleptik produk hasil substitusi tepung ubi jalar kuning dan tepung wortel pada produk biskuit terpilih K1 dengan nilai warna 4,12 (sangat suka), aroma 4,40 (sangat suka), tekstur 3,95 (suka) dan rasa 4,07 (sangat suka). Analisis gizi pada produk biskuit perlakuan terpilin K1 yaitu kadar air 4,66\%, kadar abu 2,16\%, kadar lemak 15,91\%, kadar protein 5,44\%, kadar karbohidrat 71,83\% dan kadar $\beta$-karoten 2,15 mg/g.

\section{DAFTAR PUSTAKA}

Aminah S., Tamrin dan Baco AR. 2018. Pengaruh Substitusi Tepung Ampas Kelapa dan Wortel (Daucus carota L) terhadap Nilai Organoleptik dan Nilai Gizi Cookies. J. Sains dan Teknologi Pangan. 3 (5) : 1652-1662.

Astuti WV. 2004. Subtitusi Parsial Tepung Wortel terhadap Tepung Terigu pada Pembuatan Biskuit Tinggi Serat Makan dan Betakaroten. Fakultas Pertanian Universitas Lampung. Lampung.

AOAC. 2005. Official methods of analysis. Washington DC.US.

Claudia EJ dan Widjanarko SB. 2016. Studi Daya Cerna (In Vitro) Biskuit Tepung Ubi Jalar Kuning dan Tepung Jagung Germinasi. Jurnal Pangan dan Agroindustri. 4 (1) : 391-399.

Claudia R., Estiasih T, Ningtyas DW dan Widyastuti E. 2015. Pengembangan Biskuit dari Tepung Ubi Jalar Oranye (Ipomoea batatas L) dan Tepung Jagung (Zea Mays) Fermentasi. Kajian Pustaka. Jurnal Pangan dan Agroindustri. 3 (4) : 1589-1595.

Erawati CM. 2006. Kendali Stabilitas Betakaroten Selama Proses Produksi Tepung Ubi Jalar (Ipomoea batatas L). Thesis. Program Studi Ilmu Pangan, Institut Pertanian Bogor. Bogor.

Febrina Y. 2012. Pengaruh Penambahan Tepung Wortel terhadap Daya Terima dan Kadar Vitamin A pada Biskuit. Skripsi. Fakultas Kesehatan Masyarakat, Universitas Sumatera Utara. Medan. 
Ferawati RB dan Siskayanti. 2014. Kajian Teknologi Pembuatan Tepung Ubi Jalar Instan Kaya Pro Vitamin A. Skripsi. Fakultas Teknologi Pertanian, IPB. Bogor.

Firza M. 2014. Pengaruh Substitusi Tepung Wortel (Daucus carota L) dalam Pembuatan Biskuit terhadap Mutu Organoleptik dan Kadar Serat. [KTI]. Poltekkes Kemenkes Padang. Padang.

Hardianti., Ansharullah dan Rejeki S. 2018. Pengaruh Substitusi Tepung Wortel (Daucus carota L) dan Tepung Kedelai (Glycine Max) Terhadap Nilai Gizi Biskuit sebagai MPASI Bagi Bayi. Jurnal Sains dan Teknologi Pangan. 3 (4) : 1521-1530.

Hardiyanti SM. 2018. Analisis Kandungan Zat Gizi Muffin Ubi Jalar Kuning (Ipomoea batatas L) sebagai Alternatif Perbaikan Gizi Masyarakat. Skripsi. Jurusan Kesehatan Masyarakat Fakultas Kedokteran dan IImu Kesehatan Universitas Islam Negeri Alauddin Makassar. Makassar.

Hariko M. 2013. Pengaruh Subtitusi Wortel Terhadap Organoleptik Mie Basah. Karya Tulis IImiah. Poltekes Kemenkes Padang. Padang.

Hastuti RD. 2011. Kue Kering Kaya $\beta$-Karoten dengan Penambahan Tepung Wortel (Daucus carota L). Laporan Tugas Akhir. Program Studi Diploma III Teknologi Hasil Pertanian, Fakultas Pertanian Universitas Sebelas Maret. Surakarta.

Kurniawati L. 2010. Pemanfaatan Bekatul dan Ampas Wortel (Daucus carota L) dalam Pembuatan Cookies. Jurnal Teknologi Hasil Pertanian. 3 (2) : 1632-1642.

Ma'hadah R. 2015. Pemanfaatan Tepung Wortel sebagai Sumber Vitamin A pada Beras Analog. [KTI]. Fakultas Teknologi Pangan dan Agroindustri. Universitas Mataram. Mataram.

Margaret OS. 2010. Pengaruh Proporsi Tepung Ubi Jalar Kuning dan Tepung Terigu Terhadap Sifat Fisikokimia dan Organoleptik Biskuit Manis. Skripsi. Program Studi Teknologi Pangan, Fakultas Teknologi Pertanian. Universitas Katolik Widya Mandala Surabaya. Surabaya.

Nindrayani., Krisna A, Sutardi dan Suparmo. 2011. Karakeristik kimia, fisik dan inderawi tepung ubi jalar ungu (Ipomoea Batatas Poiret) dan produk olahannya. AGRITECH. 31 (4) : 273-280.

Omobuwoajo TO. 2003. Compotisional Characteristics and Sensory Quality of Biscuit, Prawn Cracer and Fried Chips Produced From Breedfruit. J. Food Sci \& Emernging Tech. 4 (3) : 219-225.

Putri EP. 2015. Pembuatan Biskuit Komposit Tepung Ubi Jalar Kuning (Ipomoea batatas L) Varietas Jago. Skripsi. Jurusan Pendidikan Kesejahteraan Keluarga. Fakultas Teknik, Universitas Negeri Semarang. Semarang.

Rahmayani., Yaumi N dan Agustini F. 2017. Carbed (Carrot Bread) sebagai Sayuran Instan untuk Anak Kekurangan Vitamin A. Industrial Research Workshop and National Seminar. Politeknik Negeri Bandung. Bandung.

Riganakos KA And Kontominas MG. 1995. Effect of heat treatmen on moisture sorption behavior of weath flour using a hygrometrick tehnique. G.Charalambous (ED). Food flavors. Journal Generation Analysis and Process Influence. 3 (7) : 995-1005.

SNI (Standar Nasional Indonesia). 2011. Uji Bahan Makanan dan Minuman. Badan Standardisasi Nasional SNI 01-2891-2011. 
Subandoro RH., Basito dan Atmaka W. 2013. Pemanfaatan Tepung Millet Kuning dan Tepung Ubi Jalar Kuning sebagai Subtitusi Tepung Terigu dalam Pembuatan Cookies terhadap Karakteristik Organoleptik dan Fisikokimia. Jurnal Teknosains Pangan. 2 (4) : 2302-0733.

Sugito dan Ari H. 2006. Penambahan Daging Ikan Gabus dan Aplikasi Pembekuan pada Pembuatan Pempek Gluten. Laporan Penelitian Fakultas Pertanian. Universitas Sriwijaya. Sumatera Selatan.

Sumarni. 2017. Cookies Berbahan Dasar Ubi Jalar Kuning (Ipomoea batatas L) dan Tepung Ikan Kakap Puth (Lates calcarifer bloch). Skripsi. Jurusan IImu dan Teknologi Pangan. Fakultas Teknologi dan Industri Pertanian. Universitas Halu Oleo. Kendari.

Sumarni., Ansharullah H dan Asyik N. 2017. Cookies Berbahan Dasar Ubi Jalar Kuning (Ipomoea batatas L) dan Tepung Ikan Kakap Putih (Lates calcarifer bloch). J. Sains dan Teknologi Pangan. 2 (2) : 468-477.

Standar Nasional Indonesia. 2009. SNI 01-2973-2011: Syarat mutu tepung terigu. Departemen Perindustrian. Jakarta.

Tejasari. 2005. Nilai Gizi Pangan. Graha IImu. Yogyakarta.

Winarno FG. 2004. Kimia Pangan dan Gizi Edisi Kesebelas. Gramedia Pustaka Utama. Jakarta.

Wulandari M dan Handarsari E. 2010. Pengaruh Penambahan Bekatul terhadap Kadar Protein dan Sifat Organoleptik Biskuit. Jurnal Pangan dan Gizi. 1 (2) : 365-342. 